\title{
The Determining Factor of Good Governance on Government Office Tasikmalaya City
}

\author{
$1^{\text {st }}$ Sri Sudiarti \\ Politeknik Triguna Tasikmalaya \\ Tasikmalaya, Indonesia \\ Srisudiarti485@gmail.com
}

\author{
$2^{\text {nd }}$ Nanang Rusliana \\ FEB Universitas Siliwangi \\ Tasikmalaya, Indonesia \\ nanangrusliana@unsil.ac.id
}

\author{
$3^{\text {rd }}$ Yayat Karyana \\ Universitas Islam Bandung \\ Bandung, Indonesia \\ yayatkaryana@gmail.com
}

\begin{abstract}
This research aims to analyze the determining of good governance in Tasikmalaya city government. The type of research method used by the authors is a deskriftif and associative. The method of analysis is asosaiatif which aims to analyze the relationship of two or more variables. Based on the research results it is known that the organizational culture affects the good governance variables by $41.6 \%$ with a significance value of 0.009 . The internal audit further affects the good governance variable by $54.8 \%$ with a significance value of 0.002 . Then the organizational culture and internal audit are able to explain the good governance variables of $72 \%$. With significance value 0.000 .
\end{abstract}

Keywords—organizational culture, Internal Audit and Good governance

\section{INTRODUCTION}

The organization's culture is now a conversation everywhere, both among experts and among business practitioners and executives, as the culture of the organization has much to do to make an organization more stable, more Advanced, more anticipatory to environmental change. A strong and rooted organizational culture will be able to contribute significantly to members of the organization in terms of a clear and straightforward understanding of a resolved issue. Culture has a meaningful influence on the attitudes and behaviors of members of the organization. Many evidence illustrates that the success of an organization is due to its strong culture that makes the organization more confident and ultimately more effective. In an era of globalization that is heavily laden with the change, which changes are often so fast and very difficult to predict but very large of the impact for the future of the Organization, the cultural presence of a flexible organization becomes increasingly relevant. The strategy in anticipating the changes that an organization will take should also consider the cultural aspects that have existed so far, whether the designed strategy matches the values that exist, or precisely the values that exist Thus being counter productive for the organization on its way forward. Managers especially who are at peak levels must be aware of how important it is to understand their organizational culture because of their enormous influence on member behavior. Organizational culture can also be used as a concept of drafting a change or development strategy for its organization. Organizational culture especially in an institution plays an important role. Because it will make the institution flexible, versatile and elastic, as it is a culture that will never be experienced and will be perfect if coupled with a religion that is sourced to divine revelation.

Considering the development of good governance has a high complexity and large constraints, it is necessary a step cheerful to start the renewal of governance practices. The development of good governance will be felt easier if it starts with the public service sector. Public service was chosen as the main Mobilizer and entry point because the efforts to realize values that have been characterized good governance practices in public services can be done more real and easier. Values such as efficiency, transparency, accountability, and participation can be translated relatively easily in the maintenance of public services.

City of Tasikmalaya after receiving the report of the examination Results (LHP) on the financial report of the local government (LKPD) fiscal year 2016 from BPK RI, West Java, Tasikmalaya is able to retain the highest result of a reasonable opinion No exceptions (WTP) for the regional government's financial report year 2016 and this is the seventh time WTP, although using the new financial management system that is the basic accrual in the last two years, but it does not become Constraints but instead become a huge grace at once to further improve performance, because maintaining is not an easy thing.

Tasikmalaya launches three major social policies, social policy in the education, health, and rural sectors. The social policy is supported also by the development of infrastructure, both sector infrastructure (education, health, and rural) and urban infrastructure to smooth the economy wheels in the area. The study used a framework compiled by Jayasuriya (2006). According to Jayasuriya, social policy in developing countries was born to the needs of the global neoliberalism regime to integrate citizenship into the market. Social policies aimed at improving people's welfare, especially the poor, are focused on improving community capabilities to align and align with market needs. Because it is built on the foundation of such market citizenship, and not through the establishment of a social pact that takes place in a lot of negotiations between countries, citizens, and markets, the social policy patterns in developing countries show Anti-political character and accentuate the role of active agents.

\section{LITERATURE REVIEW}

Research related to the influence of good governance, internal control and organizational culture to the performance of local governments has been conducted by 
some researchers before. Nur Azlina \& Desmiyawati (2012) examine the influence of organizational commitments, internal control and public accountability for good governance, the results show public accountability does not imradiate the influence of organizational commitment to performance organizations and also does not have an internal control influence on organizational performance. The same research was conducted by Prima Yuda (2012) who examined the influence of good governance and internal control over organizational performance. Abdullah and Herlin Arisanti (2010) examined the influence of organizational culture, organizational commitment and public accountability for organizational performance. The results of his research concluded that the organizational culture affects good governance.

More specifically, organizations rely on internal audit functions to help ensure that the risk management process, overall control sphere and performance effectiveness of business processes have been consistent with management expectations. The function of internal audit is not just required to find the problem but also be part of the solution and give the proposed improvement. Thus, the role of internal audit is not only limited as "detector" but can be more as a deterrent that is expected to support and encourage the realization of good governance.

The above definition illustrates the function of an internal audit examining all activities and the accuracy of the bookkeeping and other data generated by the organization. It aims to determine whether the financial statements presented by the Organization have been properly reported and in compliance with the standards that have been generally applied.

When the organizational culture is implemented and socialized properly, it can provide direction for each member of the organization, to achieve higher working productivity so that the objectives of the Organization are reached as well as the principles of Good Governance.

\section{RESEARCH METHOD}

The method used in this study is an exportatory. The research population of the authors is the subject of the Organization's culture and internal audit, in relation to the Organization's good governance, the regional unit of work in the Government of Tasikmalaya. Sampling uses non profibility sampling, which is when every element of the population does not have the same opportunity to be selected as the Sempel. This research uses how to gather information and elements of the population available at the time of research. The reason for using this method is due to the limited number of offices willing to participate to serve as respondents. The research samples used by the authors using questionnaires as a data collection tool are as many as 45 services. This study used the method of collecting data sources by gathering the survey that has been spread in the city Department of Tasikmalaya and then the answer from the respondents who participated in this research so as to produce primary data from The auditor who participated in the study. Multiple regression analyses were conducted to test the simultaneous influence of multiple free variables against a single variable tied to an interval scale. In other words multiple regression analyses help in understanding how many variants in a bound variable are described.

\section{RESUlTS AND DISCUSSION}

1. Influence of organizational culture of Good governance In the calculation that the author did to find out whether there is any influence of organizational culture to Good governance in the government office of Tasikmalaya can be known and calculated using SPSS. From the data processing results obtained the value of correlation coefficient ( $r$ ) of 0.645. It means the influence of organizational culture on good governance with strong categories. Further from the coefficient of determination test results obtained that the value of $\mathrm{R} 2$ is 0.416 . This means the magnitude of the role or contribution of independent variables of the organizational culture is able to explain good governance variables by $41.6 \%$.

Calculation results using SPSS version 23 obtained the value of Thitung 3.046. In the calculation of DK $=n-2=15$ $-2=13$ The value of 1.771 is obtained. If compared with this, then it is obtained that Thitung (3.046) > This (1.771) and judging by the significance of the results obtained GIS. 0.009 smaller than $\alpha$-level $=0.05$.

Because Thitung $>$ this or because the value of SIG 0.009 is smaller than $\alpha=0.05$, the test result implies that the rule of Ho's decision is rejected and Ha is accepted. It shows that at a confidence level of $95 \%$ an alternative hypothesis is acceptable meaning that organizational culture has a significant effect on good governance.

The results of the research showed that the organizational culture has a significant effect on the good governance of local government in Tasikmalaya city government which has an effect of $41.6 \%$. This means that the better the culture of the Organization, the better the quality of good governance in the local government, therefore it takes values that apply in the organization and cultivate a sense of tolerance in carrying out tasks, Especially, with regard to differing opinions and differences in individual traits.

According to Sentot Imam (2010:34) that the organizational culture refers to the unity of the common meaning system adopted by the Members who distinguish the organization from other organizations. Good corporate culture is a culture that corresponds to the value system believed by all members of the organization, taught, set, and developed continuously, functioning as an adhesive, and can be used as a reference behave to achieve organizational or corporate objectives. A strong culture is a culture that is able to bind all members of the organization, into an adhesive system, to belong together. When the organizational culture is implemented and socialized properly, it can provide direction for each member of the organization, to achieve higher working productivity so that the objectives of the Organization are reached as well as the principles of Good Governance

This results in line with the research of Keith Kefgen and Manav Thadani, (2003) that the company's culture shows an integral part of the governance mentality of a company. Furthermore, Mas Achmad Daniri (2005) expressed the success of the implementation of good governance is not 
regardless of the internal and external factors of the organization. Internal factors are various factors originating from within the company, one of which is the organizational culture. In addition, Mardiasmo, D., et. AL, (2008:97) said that the culture of local governance is a variable of main obstacles in the implementation of good governance

\section{Internal Audit Effect on Good Governance}

In the calculation that the author did to know whether there is an Internal Audit of the influence of good governance in the government of Tasikmalaya City service can be known and calculated using SPSS version 23. From the data processing results obtained the value of correlation coefficient (r) of 0.740. It means the influence of Internal Audit on Good governance with very strong categories. Further from the coefficient of test result obtained the result that the value of $\mathrm{R} 2$ square is 0.548 . This means the magnitude of the role or contributions of the Internal Audit independent variable is able to explain good governance variables at $54.8 \%$.

The result of calculation by using SPSS obtained Thitung value of 3.972. In the calculation of DK $=n-2=15$ $-2=13$ The value of 1.771 is obtained. If compared with this then it is obtained that Thitung (3.972) > This (1.771) and judging by the significance of the results obtained GIS. 0.002 smaller than $\alpha$-level $=0.05$

Because Thitung $>$ this or because the value of SIG 0.002 is smaller than $\alpha=0.05$, the test result implies that the rule of Ho's decision is rejected and $\mathrm{Ha}$ is accepted. This indicates that at a confidence level of $95 \%$ an alternative hypothesis is received meaning that internal audit has a significant effect on good governance. From the results of the research showed that the culture of Organtiation and Internal Audit has significant effect on the good governance of local government in Tasikmalaya city government which has an effect of $72 \%$. This means that, the better the culture of the organtiation and the Internal Audit carried out, the better the quality of good governance on the local government, therefore it takes guarantees, independent, objective and consulting activities designed to Increase value and improve organizational operations. This helps organizations achieve their goals by bringing a systematic and disciplined approach to evaluating and improving the effectiveness of risk management, control and governance processes.

It is in accordance with the opinions of Cartwright in Djokosantoso (2006:148) "that the culture (the company) is" a powerful determinant of people's beliefs, attitudes, and behavior ". Good corporate culture is a determinant of good corporate governance, the establishment and development of professional management, strong commitment of social responsibility of the company to its environment, and the spirit to maintain excellence Corporate. " More specifically, organizations rely on internal audit functions to help ensure that the risk management process, overall control sphere and performance effectiveness of business processes have been consistent with management expectations. The function of internal audit is not just required to find the problem but also be part of the solution and give the proposed improvement. Thus, the role of internal audit is not only limited as "detector" but can be more as a deterrent that is expected to support and encourage the realization of good governance.

The same research was conducted by Prima Yuda (2012) who examined the influence of good governance and internal control over organizational performance. Abdullah and Herlin Arisanti (2010) examined the influence of organizational culture, organizational commitment and public accountability for organizational performance. The results of his research concluded that the organizational culture and internal audit affect good governance.

\section{CONCLUSION}

1. The culture of the Organization at the office in Tasikmalaya City includes a good category with an indicator of ability in supervisory ability and the need for reward. The Internal Audit of the Dinas in Tasikmalaya City has included a good category on the working Quantity indicator. Good Governance in the new town of Tasikmalaya belongs to a good category on responsive indicators.

2. There is a partial influence of the organization culture and Internal Auidt to Good governance in the city office in Tasikmalaya

3. There is a simultaneous and significant influence on the organization culture and Internal Audit of Good Governance in the city of Tasikmalaya

\section{Recommendation}

1. To improve good governance through organizational culture, we recommend that the head of Dinas create good care towards the subordinate or fellow staff in order to cause a sense of having an organization and prioritize the organization rather than oneself.

2. The implementation of internal audit has been implemented properly but still need to be improved in terms of delivering the audit results that have been done. Thus, auditors need to convey the audit results by communicating transparently and openly so that no misunderstanding occurs. The skills and technical ability of internal auditors also need to be improved even if they have an educational background that complies with the Internal Audit profession standards, this is because the more exciting the inspection objects are faced so the need to participate Ongoing education and training. Furthermore, Internal Auditor has not fully implemented the policies and procedures in writing, this should always be done because the written policy can be used as reference and used as guidelines by examiner staff, although The policy sometimes changes according to the examination period.

3. Implementation of good governance in the city Department of Tasikmalaya has been implemented well. The author hopes that Tasikmalaya city government can maintain better implementation of good governance principles.

4. Further researchers are expected to add variables that can affect good governance with a number of samples more. 


\section{REFERENCES}

[1] Agus Dwiyanto. 2008. Mewujudkan Good Governance Melalui Pelayanan Publik. Yogyakarta: Gadjah Mada University Press.

[2] Ambar Teguh Sulistiyani. 2011. Memahami Good Governance: Dalam Perspektif Sumber Daya Manusia. Yogyakarta: Gava Media

[3] Anis Chariridan Imam Ghozali (2003). Teori Akuntansi. Semarang: BP UNDIP.

[4] Arens, Alvin A., Elder, Dan Beasley. 2008. Auditing Dan Jasa Assurance Pendekatan Terintegrasi Jilid I. Edisi 12. Jakarta: Erlangga

[5] Elizabeth Hanna Dan Friska Firnanti (2013). Faktor-Faktor Yang Mempengaruhi Kinerja Auditor.
[6] Mulyadi, 2002. Auditing, Edisi Keenam, Cetakan Pertama, Jakarta: Salemba Empat

[7] Sawyer, B.Lawrence Et Al.2012. Internal Auditing Sawyers, 6th Edition.Florida Institute Of Internal Auditors

[8] Robbins SP, Dan Judge. 2002. Perilaku Organisasi, Jakarta : Salemba Empat Hal

[9] Sukrisno Agoes. 2004. Auditing (Pemeriksaan Akuntansi), Edisi Ketiga, Fakultas Ekonomi Universitas Indonesia. Jakarta.

[10] Suwarto Koeshartono. 2009. Budaya Organisasi; Kajian Konsep Dan Implementasi. Yogyakarta: Universitas Atma Jaya

[11] Thereza Michiko Labesi. (2013). Analisis Penerapan Prinsip-Prinsip Good Governance.

[12] Valery G Kumaat, 2011, Internal Audit. Jakarta: Penerbit Erlangga 